\title{
PEREMPUAN BALI DALAM DUA CERITA PENDEK:SELIR SULANDRIKARYA I MADE IWAN DARMAWAN DANKAUNG BEDOLOT KARYA GEDE ARIES PIDRAWAN(SEBUAH KAJIAN ETNOGRAFI KOMUNIKASI)
}

\author{
Nyoman Deni Wahyudi dan Dewa Gede Bambang Erawan
}

Fakultas Keguruan dan Ilmu PendidikanUniversitas Mahasaraswati Denpasar

\begin{abstract}
ABSTRAK
Penelitian ini adalah penelitian deskriptif kualitatif yang bertujuan untuk (1) mengetahui pendeskripsian perempuan Bali dalam cerpen Selir Sulandri karya I Made Iwan Darmawan yang dikaji berdasarkan studi etnografi komunikasi dan (2) mengetahui pendeskripsian perempuan Bali dalam cerpen Kaung Bedolot karya Gede Aries Pidrawan yang dikaji berdasarkan studi etnografi komunikasi. Sumber data dalam penelitian ini adalah dua cerpen yakni Selir Sulandri karya I Made Iwan Darmawan dan Kaung Bedolot karya Gede Aries Pidrawan yang mengandung pendeskripsian sosok perempuan Bali. Metode penelitian yang digunakan adalah metode studi dokumentasi. Pengolahan atau analisis data dilakukan melalui reduksi data, penyajian data, penarikan simpulan, serta verifikasi data penelitian.

Penelitian ini akan memberikan luaran yakni deskripsi tentang perempuan Bali dalam dua cerita pendek dan memiliki manfaat sebagai media pembelajaran dalam perkuliahan, memperkaya bahan analisis sastra, dan memperkaya khasanah analisis wacana kritis, seni, dan budaya Indonesia khususnya Bali. Hasil penelitian ini menunjukkan bahwa dalam karya cerita pendek (cerpen) Selir Sulandri karya I Made Iwan Darmawan yang dikaji berdasarkan studi etnografi komunikasi, perempuan Bali dideskripsikan sebagai perempuan yang mengikuti garis keturunan patrilineal, berkedudukan sosial tinggi, terpaksa menikah dini demi status sosial dan politik keluarga, mengalami poligami, menjadi pelampiasan hasrat seksual laki-laki (raja/sang suami), iri, dengki, gemar menggosip, dan memiliki rasa cemburu (posesif), takluk pada kuasa laki-laki, mengalami diskriminasi, bersikap berani di tengah-tengah situasi genting, serta harus ikhlas melaksanakan ritual mesatia. Dalam cerpen Kaung Bedolot karya Gede Aries Pidrawan sosok perempuan Bali digambarkan tak jauh berbeda yakni menginginkan pernikahan yang diidamkan, mengalami poligami, mengikuti garis keturunan patrilineal, terpaksa menikah dini demi status sosial dan politik keluarga, melaksanakan pekerjaan rumah tangga, pasrah dan ikhlas menerima nasib, menjadi korban kekerasan dalam rumah tangga, bersikap berani di tengah situasi yang memojokkan, serta berakhir dengan kematian akibat kekerasan dalam rumah tangga. Hasil penelitian ini bermanfaat baik secara teoretis maupun praktis bagi mahasiswa, dosen, penikmat sastra, dan dunia pendidikan. Peneliti lain diharapkan melakukan penelitian lanjutan yang lebih mendalam.
\end{abstract}

Kata kunci:perempuan, cerita pendek, etnografi komunikasi 


\begin{abstract}
This research is a descriptive qualitative research which aims to (1) find out the descriptions of Balinese women in Sulandri's concubine by I Made Iwan Darmawan which is studied based on the study of communication ethnography and (2) to know the description of Balinese women in the short story of Kaede Bedolot by Gede Aries Pidrawan, study of ethnographic communication. Sources of data in this study are two short stories of Sulandri's concubine by I Made Iwan Darmawan and Kaung Bedolot by Gede Aries Pidrawan which contains the description of Balinese women figure. The research method used is documentation study method. Processing or data analysis is done through data reduction, data presentation, conclusion drawing, and verification of research data.

This research will provide the description of Balinese women in two short stories and has the benefit of being a learning media in the lectures, enriching the material of literary analysis, and enriching the treasury of critical discourse analysis, art, and culture of Indonesia especially Bali. The results of this study indicate that in the work of short story (short story) Selir Sulandri by I Made Iwan Darmawan who studied based on the study of communication ethnography, Balinese women described as women who follow patrilineal lineage, high social position, forced to marry early for the social and political status of the family, to experience polygamy, to impinge on the sexual desires of men (kings / husbands), jealousy, envy, gossip, and possessive jealousy, subjugation to men's power, discrimination, courage in the midst of situations critical, and must be willing to perform mesatia ritual. In the short story of Kaung Bedolot by Gede Aries Pidrawan, the figure of Balinese women is described not as different as that of wanting a coveted marriage, having polygamy, following patrilineal lineage, being forced to marry early for the social and political status of the family, doing housework, resigned and sincerely accepting fate, become victims of domestic violence, be brave in the middle of a discouraging situation, and end up with deaths from domestic violence. The result of this research is useful both theoretically and practically for students, lecturers, literature lovers, and education. Other researchers are expected to conduct further research in more depth.
\end{abstract}

Keywords: women, short stories, ethnography communication

\section{PENDAHULUAN}

Manusia sebagai makhluk sosial memerlukan suatu alat untuk bisa berhubungan antarmanusia lainnya. Bahasa adalah sebuah alat komunikasi yang dibentuk dan digunakan oleh masyarakat pembentuk sekaligus pengguna bahasa itu sendiri. Bahasa pada dasarnya tidak bisa dilepaskan dari konteks sosial dan budaya masyarakat penuturnya. Manusia belajar berpikir, merasa, memercayai, dan mengusahakan apa yang patut menurut budayanya. Bahasa, persahabatan, kebiasaan makan, praktik komunikasi, tindakantindakan sosial, kegiatan-kegiatan 
ekonomi dan politik, serta teknologi, semua itu berdasarkan pola-pola budaya.Secara formal, budaya didefinisikan sebagai tatanan pengetahuan, pengalaman, kepercayaan, nilai, sikap, makna, hirarki, agama, waktu, peranan, hubungan ruang, konsep alam semesta, objek-objek materi dan milik yang diperoleh sekelompok besar orang dari generasi ke generasi melalui usaha individu dan kelompok.

Bahasa digunakan untuk menyatakan ekspresi diri, sebagai alat komunikasi, dan sebagai alat untuk mengadakan kontrol sosial (Keraf, 2001:3). Bahasa dan sastra memiliki kaitan yang sangat erat antara satu dan yang lainnya. Sastra menggunakan bahasa sebagai medianya. Sastra merupakan refleksi atau cerminan kehidupan sosial dan budaya yang diamati oleh pengarang. Latar belakang sosial budaya dan pribadi setiap pengarang mendasari proses kreatif bersastra dan termasuk penggunaan bahasanya.Sastra dibangun dengan bahasa yang memiliki ciri khas tersendiri. Karya sastra merupakan hasil kegiatan kreatif manusia yang berkaitan dengan imajinasi, intuisi, dan abstraksi kehidupan (Suwondo, 2003:5).

Bahasa dan sastra pun tidak dapat dipisahkan dari budaya. Budaya dan komunikasi tidak dapat dipisahkan oleh karena budaya tidak hanya menentukan siapa bicara dengan siapa, tentang apa, dan bagaimana orang menyandi pesan, makna yang ia miliki untuk pesan, dan kondisi-kondisinya untuk mengirim, memperhatikan, dan menafsirkan pesan.Manusia belajar berpikir, merasa, memercayai, dan mengusahakan apa yang patut menurut budayanya. Bahasa, persahabatan, kebiasaan makan, praktik komunikasi, tindakantindakan sosial, kegiatan-kegiatan ekonomi dan politik, serta teknologi, semua itu berdasarkan pola-pola budaya.

Cerpen adalah salah satu jenis sastra prosa selain puisi dan drama. Cerpen merupakan karangan fiktif yang berisi sepenggal atau sebagian kisah kehidupan seseorang dalam suatu masyarakat sosial. Berbagai ragam tema sosial dan budaya bisa diangkat untuk dijadikan cerpen. Cerpen memiliki struktur isi yang khas, antara lain judul, pengenalan tokoh, komplikasi atau penyebab konflik, konflik, klimaks, dan antiklimaks serta penyelesaian. Bentuk tulisan cerpen tergolong wacana singkat; lebih pendek dibandingkan novel. Cerpen hanya mengisahkan sebuah kejadian singkat tentang pelaku utamanya.

Berbicara tentang kehidupan sosial sering kali berhadapan pada kesenjangan sosial. Walaupun emansipasi wanita dan kesetaraan gender sudah bergaung namun garis patrilinealisme menentukan perempuan di-minor-kan dalam komunitas sosial; peran dan fungsi laki-laki jauh lebih penting dan dihargai. Di Bali sebagian besar perempuan Bali masih memiliki anggapan bahwa kaum perempuan 
Bali masih sering mengalami penindasan. Ada yang beranggapan hal ini muncul sebagai akibat faktor budaya dan sistem kekeluargaan. Perempuan Bali memiliki banyak peran dalam kehidupan sosialnya. Sistem dan asas hukum adat serta keluarga baik perkawinan, fungsi sosial, waris, dan sebagainya menempatkan perempuan Bali di bawah kedudukan laki-laki.

Cerpen yang berjudul Selir Sulandri merupakan karya I Made Iwan Darmawan yang ditulis pada tahun 2004 dan berhasil meraih juara penulisan cerpen nasional dan dimuat dalam majalah Femina 20-26 Januari 2005. Cerpen ini mengisahkan seorang selir dari kaum bangsawan yang dinikahi raja dan mengalami konflik batin pascaperkawinannya bersama raja. Cerpen ini mendeskripsikan perempuan Bali sebagai korban politik, pernikahan, dan persaingan di tengah area puri (kerajaan). Cerpen yang berjudul Kaung Bedolot merupakan karya Gede Aries Pidrawan pada tahun 2013 yang berhasil meraih juara 1 lomba cipta cerpen Sayembara Sastra Sawtaka Nayyotama 2013. Cerpen ini mengisahkan seorang istri muda dari seorang laki-laki yang memiliki banyak istri. Konflik muncul saat sang suami tahu bisa tokoh utama tidak perawan dan mengalami siksaan baik fisik maupun batin.

Etnografi adalah kajian tentang kehidupan dan kebudayaan suatu masyarakat atau etnik, misalnya tentang adat-istiadat, kebiasaan, hukum, seni, religi, dan bahasa.
Bidang kajian yang sangat berdekatan dengan etnografi adalah etnologi, yaitu kajian perbandingan tentang kebudayaan dari berbagai masyarakat atau kelompok.Etnografi komunikasi merupakan suatu ancangan yang berusaha untuk menganalisis polapola komunikasi sebagai bagian dari pengetahuan kultural dan perilaku. Pendapat ini berimplikasi pada pengakuan terhadap adanya keragaman praktik komunikasi (misalnya sesuai dengan relativitas kultural) serta fakta adanya keragaman praktik komunikasi itu merupakan bagian yang terpadu tentang apa yang diketahui dan lakukan.

Beranjak dari uraian latar belakang di atas maka penulis melakukan sebuah penelitian yang berjudul "Perempuan Bali dalam Dua Cerita Pendek: Selir Sulandri Karya I Made Iwan Darmawan dan Kaung Bedolot Karya Gede Aries Pidrawan (Sebuah Kajian Etnografi Komunikasi)".

Berdasarkan uraian latar belakang di atas maka penulis dapat merumuskan permasalahan dalam penelitian ini antara lain (1) bagaimanakah pendeskripsian perempuan Bali dalam cerpen Selir Sulandri karya I Made Iwan Darmawan yang dikaji berdasarkan studi etnografi komunikasi, dan (2) bagaimanakah pendeskripsian perempuan Bali dalam cerpen Kaung Bedolot karya Gede Aries Pidrawan yang dikaji berdasarkan studi etnografi komunikasi? 


\section{METODE PENELITIAN}

Penelitian ini dilakukan dengan menggunakan pendekatan deskriptif kualitatif. Pendekatan penelitian dengan deskriptif kualitatif dengan cara mendeskripsikan faktafakta yang terjadi secara alamiah. Model penelitian ini mendeskripsikan informasi apa adanya sesuai dengan variabel, gejala, atau keadaan yang diteliti untuk kemudian dimaknai atau diapresiasi. Penelitian deskriptif adalah suatu bentuk penelitian yang ditujukan untuk mendeskripsikan fenomena-fenomena yang ada, baik fenomena alamiah maupun fenomena buatan manusia (Aries, 2008).Pada penelitian deskriptif kualitatif, peneliti berusaha menggambarkan kegiatan penelitian yang dilakukan pada objek tertentu secara jelas dan sistematis. Dengan demikian, penelitian ini ingin mendeskripsikan dan menginterpretasikan perempuan Bali dalam dua cerita pendek (cerpen) yakni Selir Sulandri karya I Made Iwan Darmawan dan Kaung Bedolot karya Gede Aries Pidrawan yang ditinjau dari kajian etnografi komunikasi.

Sumber data dalam penelitian ini adalah cuplikan tuturan yang digunakan oleh tokoh-tokoh serta ilustrasi yang terdapat pada dua cerpen yakni Selir Sulandri karya I Made Iwan Darmawan dan Kaung Bedolot karya Gede Aries Pidrawan yang mengandung pendeskripsian sosok perempuan Bali. Tuturan yang digunakan sebagai sumber data pada penelitian ini diambil dari dua cerpen tersebut didasarkan atas beberapa pertimbangan, antara lain cerpencerpen tersebut memiliki penggambaran masalah yang dihadapi oleh kaum perempuan Bali baik dalam kehidupan pribadi, keluarga, dan sosialnya. Kedua cerpen yang diteliti juga menggambarkan penggunaan bahasa yang mengandung pendeskripsian sosok perempuan Bali dan bisa dianalisis dengan tinjauan etnografi komunikasi.

Objek penelitian adalah hal yang dikaji dalam penelitian. Objek dalam penelitian ini adalah pendeskripsian tokoh perempuan Bali yang terdapat dalam dua cerita pendek (cerpen). Secara lebih rinci, objek penelitian ini antara lain pendeskripsian (1) perempuan Bali dalam cerpen Selir Sulandri karya I Made Iwan Darmawan dan (2) perempuan Bali dalam cerpen Kaung Bedolot karya Gede Aries Pidrawan. Kedua objek penelitian ini dianalisis berdasarkan kajian studi etnografi komunikasi.

Data yang didapatkan dalam penelitian ini dikumpulkan melalui studi dokumentasi. Teknik yang digunakan untuk mengumpulkan data-data dalam penelitian ini adalah pencatatan dokumen. Moleong (2004:160-165) menyatakan bahwa pengumpulan data dengan menggunakan studi dokumentasi itu dapat dimulai dari pengenalan objek, pencatatan data, dan seleksi data. Peneliti menggunakan metode studi dokumentasi untuk mengumpulkan 
data penelitian. Metode studi dokumentasi adalah suatu metode yang digunakan untuk mengumpulkan data mengenai suatu variabel yang diteliti dari catatan atau naskah tertulis. Instrumen yang digunakan untuk mengumpulkan data dalam penelitian ini adalah kartukartu data. Kartu data yang digunakan berisi garis-garis besar kategori data yang bersangkutan. Perangkat pengumpulan data yang berupa kartu data ini berukuran A5. Dalam kartu data tersebut berisi hal-hal sebagai berikut: (a) nomor data, (b) jenis data, (c) keterangan data, (d) catatan atau kutipan data (dilengkapi dengan situasi atau konteks tutur), dan (e) analisis data.

$\begin{array}{llr} & \text { Karena peneliti bertindak } \\ \text { sebagai instrumen utama atau } & \\ \text { instrumen kunci, ada kemungkinan } \\ \text { unsur subjektivitas peneliti }\end{array}$
membiaskan data penelitian ini. Untuk menekan hal tersebut, bahkan meniadakan subjektivitas tersebut sehingga bias tersebut dapat diminimalkan, peneliti perlu memeriksa keabsahan data yang dikumpulkan. Teknik pengujian keabsahan data yang peneliti gunakan antara lain ketekunan pengamatan dan pengecekan melalui teman sejawat.

Ketekunan pengamatan dapat memberikan wawasan bagi peneliti. Kedalaman wawasan ini memungkinkan peneliti untuk menemukan ciri-ciri dan unsur-unsur situasi yang relevan dengan permasalahan yang diteliti kemudian memusatkan diri pada hal-hal tersebut secara rinci. Teknik pemeriksaan melalui teman sejawat dilaksanakan dengan jalan mengekspos hasil sementara atau hasil akhir yang diperoleh dalam bentuk diskusi analitis dengan teman-teman sejawat yang mendalami bidang ilmu yang sama, yaitu dosen pengajar sastra, sastrawan, dan penulis cerpen yang bersangkutan.

Analisis data di dalam penelitian kualitatif dilakukan bersamaan dengan proses pengumpulan data.Analisis yang digunakan dalam penelitian ini adalah analisis nonstatistik. Analisis data dilakukan secara induktif. Mengolah data secara induktif artinya mengolah data yang berupa fakta-fakta, sehingga dapat ditarik suatu simpulan yang bersifat umum (Zuriah, 2006:93).Namun, simpulan umum yang diperoleh tersebut tidak digunakan untuk menggeneralisasikan suatu gejala. Analisis data di dalam penelitian kualitatif dilakukan bersamaan dengan proses pengumpulan data. Dengan demikian, temuan peneliti di lapangan yang kemudian dibentuk ke dalam bangunan teori, bukan dari teori yang telah ada, melainkan dikembangkan dari data lapangan (induktif).

Peneliti segera melakukan analisis data dengan memberi paparan atau memberi gambaran mengenai situasi yang diteliti dalam bentuk naratif verbal. Objektivitas pemaparan harus dijaga sedemikian rupa agar subjektivitas peneliti dalam membuat interpretasi dapat dihindari.Data yang dikumpulkan dalam penelitian ini dianalisis secara 
kualitatif. Analisis data dilakukan setiap saat pengumpulan data secara berkesinambungan.Adapun langkahlangkah yang ditempuh oleh peneliti dalam pengolahan atau analisis data yang diperoleh antara lain reduksi data, penyajian data, penarikan simpulan serta verifikasi data penelitian.

\section{HASIL DAN PEMBAHASAN}

Pada bagian ini, peneliti memaparkan data yang berkaitan dengan masalah yang dikaji dalam penelitian ini. Masalah-masalah tersebut antara lain pendeskripsian perempuan Bali dalam cerpen Selir Sulandri karya I Made Iwan Darmawan yang dikaji berdasarkan studi etnografi komunikasi dan pendeskripsian perempuan Bali dalam cerpen Kaung Bedolot karya Gede Aries Pidrawan yang dikaji berdasarkan studi etnografi komunikasi.

Dalam setiap sajian data, data tersebut secara langsung dianalis dan dimaknai. Setelah data pada setiap masalah tersebut dianalisis dan dimaknai, penulis menarik simpulan sementara. Data yang merepresentasikan perempuan Bali dalam cerpen Selir Sulandri karya I Made Iwan Darmawan diberi kode data PB.SS, sedangkan data yang merepresentasikan perempuan Bali dalam cerpen Kaung Bedolot karya Gede Aries Pidrawan diberi kode data PB.KB. Data PB.SS yang ditemukan dan disajikan dalam pembahasan adalah sebanyak 10 data dan data PB.KB yang ditemukan dan disajikan dalam pembahasan adalah sebanyak 9 data.

Data-data tersebut selanjutnya dimasukkan ke dalam kartu-kartu data yang selanjutnya dianalisis berdasarkan kajian etnografi komunikasi. Sajian data dan analisis masing-masing data berdasarkan tinjauan etnografi komunikasisecara umum disajikan dalam tabel sebagai berikut.

Tabel 1. Pendeskripsian Perempuan Bali dalam Cerpen Selir Sulandri dan Kaung Bedolot

\begin{tabular}{|c|c|}
\hline No & Pendeskripsian Perempuan Bali \\
\hline 1. Selir Sulandri & $\begin{array}{ll}\text { a. } & \text { mengikuti garis keturunan } \\
\text { patrilineal } \\
\text { b. berkedudukan sosial tinggi } \\
\text { c. terpaksa menikah dini demi } \\
\text { status sosial dan politik } \\
\text { keluarga } \\
\text { d. mengalami poligami } \\
\text { e. menjadi pelampiasan hasrat } \\
\text { feksual raja (sang suami) } \\
\text { f. iri, dengki, gemar menggosip, } \\
\text { dan memiliki rasa cemburu } \\
\text { g. takluk pada kuasa laki-laki } \\
\text { h. mengalami diskriminasi }\end{array}$ \\
\hline
\end{tabular}




\begin{aligned} \hline i. $\quad \begin{array}{l}\text { bersikap berani di tengah- } \\ \text { tengah situasi genting }\end{array} \\$ j. $\begin{array}{l}\text { harus ikhlas melaksanakan } \\ \text { ritual mesatia }\end{array} \\$ a. $\quad \begin{array}{l}\text { menginginkan pernikahan yang } \\ \text { diidamkan }\end{array} \\$ b. $\quad$ mengalami poligami \\ c. $\quad \begin{array}{l}\text { mengikuti garis keturunan } \\ \text { patrilineal }\end{array} \\$ d. $\quad \begin{array}{l}\text { terpaksa menikah dini demi } \\ \text { status sosial dan politik } \\ \text { keluarga }\end{array} \\$ e. $\quad \begin{array}{l}\text { melaksanakan pekerjaan rumah } \\ \text { tangga } \\ \text { pasrah dan iklhas menerima } \\ \text { nasib } \\ \text { genjadi korban kekerasan }\end{array} \\$ m. $\begin{array}{l}\text { dalam rumah tangga } \\ \text { bersikap berani di tengah situasi } \\ \text { memojokkan }\end{array} \\$ i. $\quad \begin{array}{l}\text { berakhir dengan kematian } \\ \text { akibat kekerasan dalam rumah } \\ \text { tangga }\end{array} \\$\hline\end{aligned}

Temuan-temuan dalam penelitian ini selanjutnya dianalisis berdasarkan kajian etnografi komunikasi yang merupakan landasan analisis menurut ujaran-ujaran antarpelaku yang terdapat dalam tuturan yang muncul dalam kedua cerpen, baik dalam cerpen Selir Sulandri dan Kaung Bedolot. Hal ini mampu memberikan gambaran komprehensif tentang deskripsi atau penggambaran perempuan Bali dalam kedua cerita pendek tersebut, baik tokoh utama maupun tokoh pendukung berdasarkan analisis kajian etnografi komunikasi.

\section{SIMPULAN DAN SARAN}

Berdasarkan pemaparan di atas maka peneliti dapat menyimpulkan bahwa secara umum pendeskripsian perempuan Bali dalam cerita pendek Selir Sulandri Karya I Made Iwan Darmawan dan Kaung Bedolot Karya Gede Aries Pidrawan dapat dianalisis berdasarkan kajian etnografi komunikasi. Hasil penelitian ini menunjukkan bahwa dalam karya cerita pendek (cerpen) Selir Sulandri karya I Made Iwan Darmawan yang dikaji berdasarkan studi etnografi komunikasi, perempuan Bali dideskripsikan sebagai perempuan yang mengikuti garis keturunan patrilineal, berkedudukan sosial tinggi, terpaksa menikah dini demi status sosial dan politik keluarga, mengalami poligami, menjadi pelampiasan hasrat seksual raja (sang suami), iri, dengki, gemar menggosip, dan memiliki rasa cemburu, takluk pada kuasa laki-laki, mengalami 
deskriminasi, bersikap berani di tengah-tengah situasi genting, harus ikhlas melaksanakan ritual mesatia. Dalam cerpen Kaung Bedolot karya Gede Aries Pidrawan sosok perempuan Bali digambarkan tak jauh berbeda yakni menginginkan pernikahan yang diidamkan, mengalami poligami, mengikuti garis keturunan patrilineal, terpaksa menikah dini demi status sosial dan politik keluarga, melaksanakan pekerjaan rumah tangga, pasrah dan iklhas menerima nasib, menjadi korban kekerasan dalam rumah tangga, bersikap berani di tengah situasi memojokkan, serta berakhir dengan kematian akibat kekerasan dalam rumah tangga.

Hasil penelitian ini dapat dijadikan bahan pembelajaran tentang penggunaan bahasa dalam karya sastra. Para pengajar bisa memilih karya-karya sastra khususnya sastra cerpen yang mampu merepresentasikan suatu hal yang dikaitkan dengan konteks sosial dan dianalisis berdasarkan implikasi pragmatisnya karena pada dasarnya sastra merupakan refleksi keadaan masyarakat dan bahasa yang digunakan sesuai dengan bahasa yang digunakan di masyarakat. Hasil penelitian ini juga bisa dijadikan dasar pertimbangan dalam pengajaran sastra atau model analisis sastra dengan penggunaan cerpen bagi dosen Bahasa dan Sastra Indonesia terutama dalam pembelajaran Sosiolinguistik, Pragmatik, Teori Sastra, Prosa Fiksi, Kritik Sastra, Analisis Wacana, Drama, dan sebagainya. Pembaca khususnya peneliti lain diharapkan mampu melakukan penelitian lanjutan mengenai permasalahan yang serupa dengan penelitian ini yakni pendeskripsian perempuan dalam sastra, sastra feminis, serta hal-hal lain yang bisa dikaji melalui teori sosiolinguistik, pragmatik, atau etnografi komunikasi.

\section{DAFTAR PUSTAKA}

Aries, E. F. (2008). Penelitian Deskriptif. http://ardhana12.wordpress.c om/ 2008/02/27/penelitiandeskriptif/. Diunduh pada 17 Oktober 2011.

Moleong, L J. (2004). Metodologi Penelitian Kualitatif. Bandung: PT Remaja Rosdakarya.

Schiffrin, D. (2007). Ancangan Kajian Wacana. Yogyakarta: Pustaka Pelajar.

Suwondo, T. (2003). Studi Sastra: Beberapa Alternatif. Yogyakarta: Hanindita Graha Widya.

Zuriah, N.(2006). Metodelogi Penelitian Sosial dan Pendidikan. Jakarta: Bumi Aksara. 